\title{
THE LABORATORY DIAGNOSIS OF INFLUENZA
}

\author{
T. H. FlewetT, M.D. \\ Consultant Virologist, East Birmingham Hospital, Birmingham
}

THE laboratory diagnosis of influenza comes under two headings: the diagnosis of an influenza epidemic; and the precise diagnosis of illness in patients. But the papers already given to this gathering have shown the need for rapid identification of the agent likely to fill hospital beds, so that due preparation for the load of admissions may be made. Early precise virological diagnosis of an influenza outbreak is also needed; influenza $A$, especially if the virus shows any appreciable serological variation from the type previously prevalent, has been found more likely to spread far and wide than influenza $\mathrm{B}$; influenza $\mathrm{C}$ does not cause significant epidemics. Prompt isolation of a new and especially virulent virus in a country on the other side of the world should enable a fair amount of vaccine to be made here and people specially at risk to be immunized-chronic bronchitics, diabetics, medical staff, etc., before the epidemic built up here.

Virological diagnosis is also required to characterize the range of clinical pictures being produced by the virus. For example, in the 1960-61 outbreak of influenza, I rang up different hospitals in this Region to ask whether their nurses were going down with 'flu.--nurses' homes usually are affected at an early stage-I got the answer 'No, the girls haven't 'flu., but there is a wave of heavy colds going round'. We were able to show later that some at least of these 'colds' were due to influenza virus. At the same time we were isolating influenza virus from the lungs of a man who had dropped dead in the street with a fulminant virus pneumonia of the kind described by Dr. Parker.

\section{Virus Isolation}

For virus isolation, throat and/or nose swabs, or, better still, garglings are taken. The patient is asked to gargle with ro ml. of tissue culture medium (Hanks' solution containing $0.3 \%$ lactalbumin hydrolysate and $0.1 \%$ bovine plasma albumen). Sterile skimmed milk, or a mixture of one part bacteriological broth and three parts of sterile saline, also serve. If a swab is taken it should be a good juicy one. The end of the wooden stick bearing the cotton wool is then broken off into $2 \mathrm{ml}$. of one of the above media in a 'bijou' bottle.
Serum or clotted blood should be sent to the viruts laboratory as soon as possible and again about I4 days later. Pieces of tissue-lung and trachea especially-are best put in a dry sterile screwto capped jar.

Specimens, unless they are to be sent a long was are best not frozen solid, but cooled on wet ice्e. A vacuum jar is not necessary; a large empto dried milk tin does quite well. In this thes specimens may be sent by train 'to be collectes? or put on a bus or van. Sera can be posted. Mange viruses, especially 'respiratory syncytial' and parainfluenza 3 virus, are killed by being frozen solid. For those who have to send specimens through the post the British Oxygen Co. sell a portable outfit which enables one to freeze rapidf a small container with $\mathrm{CO}_{2}$ from a cylinder; enough dry ice is thus made to keep the sanople frozen until the next day in the insulating $50 \%$ provided. However, specimens sent on wetgage by train from Hereford have yielded plenty of influenza virus in Birmingham several hours after dispatch, while we have consistently failed to isolate respiratory syncytial virus from specimeno frozen solid with dry ice.

Isolation of influenza virus $A$ is most easil accomplished by inoculation of garglings into the amniotic cavity of chick embryos, of about I I to I 3 days incubation. The eggs are then incubated for four days; in our experience the isqlation rate is higher after four days than after three days incubation. This difference in isolation rate appeared to be greater with the I960-6I viruseg than with the $1957-5^{8}$ viruses. An occasiona isolation is successful only after subculture into a second set of eggs by the same route. Success is shown by agglutination of hen's blood cells by the virus. Pre-Asian varieties of influenza A woul fully agglutinate only human or guinea-piog erythrocytes when first isolated, but the Asians

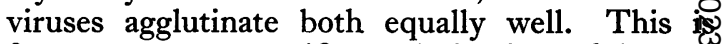
fortunate; non-specific agglutination of humat group $\mathrm{O}$ and guinea-pig cells is sometimes producę by normal amniotic fluid of 17-day-old egge in any case influenza $C$ agglutinates only chick celk and only at $4^{\circ} \mathrm{C}$. Examination of the amniotio fluid infected by influenza $\mathrm{A}$ or $\mathrm{C}$ viruses by the dark-background microscope usually shows numf 


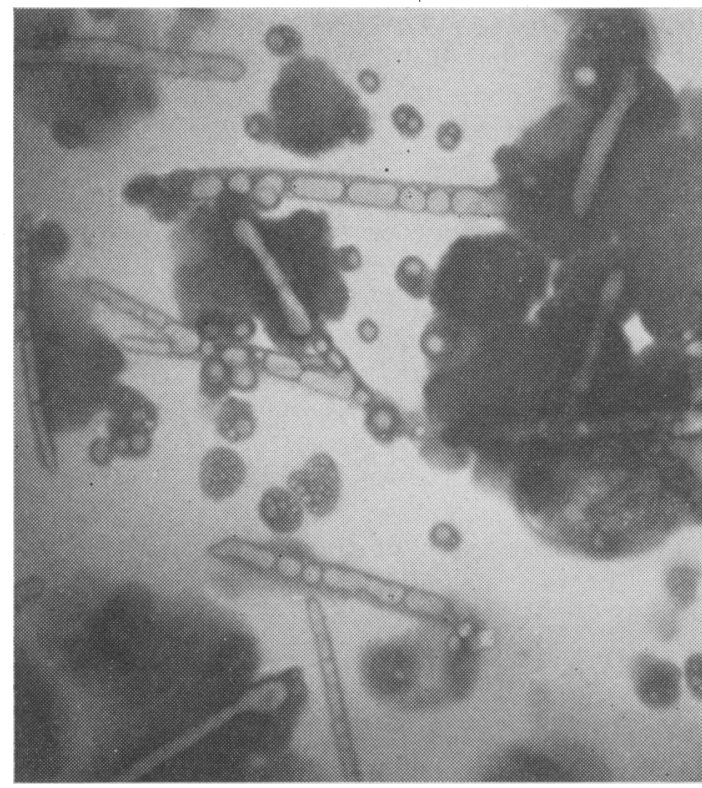

FIG. I.-Amniotic fluid mixed with washed fragments of erythrocyte membrane, stained with $\mathrm{O}_{5} \mathrm{O}_{4}$. x 40,000 .

bers of faint, often jointed, fairly rigid filaments. These are seen by the light scattered from them, though their diameter is well below the resolving power of the light microscope. In amniotic fluids of normal eggs giving non-specific hæmagglutination short filaments in small numbers are often visible in this way. These were looked at by electron microscopy; a suspension of washed erythrocyte fragments was mixed with such a fluid, allowed to stand for an hour at $4^{\circ} \mathrm{C}$., fixed with osmic tetroxide and mounted on copper grids. The result is this 'problem picture of the year' (Fig. I). It is not a phosphotungstate negative-stained preparation; it does look like one, though these filaments do not look like virus particles.

Virus isolation (except for influenza C) may also be accomplished by inoculation of tissue culture with material, collected as for egg inoculation; monkey kidney (rhesus or cynomologus) has been mostly used. Both influenza $A$ and $B$ viruses produce a visible cytopathic effect, but, like the parainfluenza viruses, they are most easily and rapidly detected by putting a suspension of guineapig erythrocytes into the culture tube; when virus is growing in the cultured cells, erythrocytes adhere (Fig. 2). This adhesion is specifically prevented by the appropriate antiserum, and so the virus can be rapidly identified.

Tissue cultures of monkey kidney have one great disadvantage; they frequently harbour

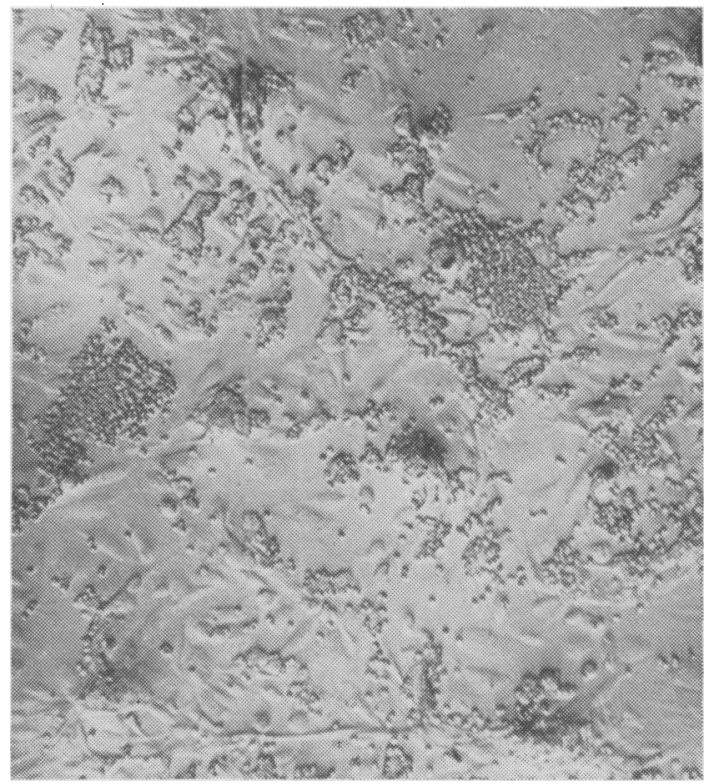

Fig. 2.-Monkey kidney tissue cultures infected with influenza virus, showing hæmadsorption. $\quad$ x 60 .

latent viruses. The commonest of them, known as $\mathrm{SV}_{5}$, is a myxovirus, which, like influenza and parainfluenza viruses, agglutinates human and guinea-pig erythrocytes and which produces eventually a characteristic cytopathic effect. The manifestation of this virus can be prevented to some extent by incorporating anti-SV $\mathrm{S}_{5}$ serum in the medium, but a better answer is probably to use calf kidney or human thyroid tissue cultures for respiratory virus investigations. Both of these support growth of influenza A and B and parainfluenza viruses, and are less likely to be contaminated with latent viruses. They will not, however-especially calf kidney-serve to isolate the many other human respiratory viruses, e.g. adenoviruses and enteroviruses, which the monkey-kidney cultures can detect.

More precise identification has to wait until cell-free hæmagglutinin is available, either from eggs or tissue cultures. Inhibition of hæmagglutinin by antisera is highly strain-specific with the influenza viruses and is the means employed for discriminating between closely related influenza A viruses. I do not propose to go into the details of how this is done, and of the various precautions one has to take to avoid being led up the garden path; the method has been published by Isaacs, Hart and Law (196I).

Attempts to isolate a virus from patients with Asian influenza is not always successful. If a throat washing is taken early in the course of infection the isolation rate is high, probably better 
than $50 \%$; Jensen, Dunn and Robinson (1958), wrote that there was a big difference in isolation rates between different laboratories. We found that virus can nearly always be isolated from lungs within 24 hours of death from acute influenza when the body is kept in a refrigerated mortuary, but rarely after a longer interval, though we once isolated A2 virus from the trachea 44 hours after death. Different strains of influenza $B$ vary greatly in the ease with which they are isolated. Some have been more readily isolated in monkeykidney tissue cultures than in eggs, as in the South of England in 1961-62, though in Birmingham and laboratories further north the prevailing $B$ virus was hard to isolate by either method. Maassab (196r) has claimed that tissue cultures of chick-embryo kidney are easy to prepare and that they afford a useful and easy means of isolating both influenza $A$ and $B$ viruses, and that the $B$ virus is more readily isolated in this system than in the amniotic cavity of the chick embryo. Influenza $\mathbf{C}$ is rarely isolated by any method.

\section{Serology}

Investigations of patients' paired sera for a rise of titre for complement fixing (CF) antibodies or hæmagglutination-inhibiting (HI) antibodies is the easiest way of making a diagnosis, especially when large numbers are being investigated. But these methods are not infallible. Clarke, Heath, Sutton, Sutton and Stuart-Harris (1958) claimed that both these tests were positive only in about $70 \%$ of patients with clinically typical influenza in 1957-58; Jensen (196r) and Dr. Hearn's figures confirm these findings. The method has the further disadvantage that it takes Io to I4 days after the onset to get an answer, by which time the patient is usually better or dead.

The titre of CF antibodies diminishes fairly quickly after convalescence and usually falls from the common peak level of $I: 64$ or higher to $I: I 6$ or less within three months, though in a few patients the titre may perhaps fall more slowly. A very high titre therefore ( $1: 64$ or above), in a single serum affords good presumptive evidence that the patient has had recent infection (Grist, Kerr and Isaacs, I96I). Because of this, the CF titres alone found in sera of the hospital population may be a useful guide in revealing the presence of an influenza epidemic even before the first isolation is made, especially if the virus is very hard to isolate. Fig. 3 shows the number of sera submitted week by week to us having titres of I: 16 or above against influenza $A$ virus over the last few years and you will see that a sudden rise in CF titres has followed hard on the heels of the first isolation or even, as in $1962-63$, preceded it.
Diagnosis of Epidemics
I am sure that it is in the military barracks, $\frac{2}{3}$ boarding schools, and especially the hospitals, 2 that the watch should be kept for the first appearance of influenza. Before a G.P. has made acs clinical diagnosis of influenza he has probablyo sent into hospital one or two chronic bronchiticso who are not feeling very well and are suddenly $\overline{\bar{p}}$. more breathless, the hospital pathologist has seen $\mathbb{\Omega}$ at autopsy the first lungs with bright red bronchialo linings, and six nurses have reported sick when one had gone sick the week before. Indeed Dr. $\vec{\circ}$ Hearn has already told you of the way in which $\overrightarrow{\vec{\omega}}$ one can walk round a ward of chronic bronchiticso and make the diagnosis of epidemic influenzaco simply by inspection of the temperature charts, several having in common an almost simultaneousce spike of fever and pulse rate. Having recognized: this in 1957 he has rung me up on several occasions since to say 'The 'flu. is back' on seeing thise' pattern again, and each time he has been right.ळ Only once did I already know from other evidence.

Though it is virtually impossible to provevisitors cannot be excluded as a source- $I \bigcirc$ strongly suspect that this pattern of temperatureo and pulse change often indicates cross-infection@ with influenza virus within the ward. This wass especially so in 1957 and 1958 and again this ye when only an occasional ward showed the patter and when it was almost the first indication of virus infection reappearing in the community.

Everybody complains that by the time they hearo from the laboratory what the patient has got heo is better and has gone home. A really rapid $\mathscr{Q}$ diagnostic technique would be of great value. $\overrightarrow{\vec{B}}$ This exists but is tricky, and works as follows. 3 Sputum in influenza contains exfoliated infected cells. These contain antigen. This antigen can? be frequently detected by staining with specifico을 fluorescent antibody. The method has been used diagnostically by Liu (1956, 196r), and by Hers 3 (1960) and Hers and Mulder (196r), but has never. been extensively exploited because it is technically difficult and also because it only answers the question 'is this influenza $A$ ' (or $B$, etc., as the ? case may be); it is not a method, like tissue culture $\frac{}{5}$ inoculation, lending itself to 'screening' for many different viruses. But if effective antiviral sub- $N$ stances should be discovered which have to be tailored for a particular variety of myxovirus, as the thiosemicarbazones must be for the poxviruses, $\omega$ then very rapid virus identification will become really important.

One other possible method of rapid diagnosis looms over the horizon and has so far hardly been ${ }_{+}^{+}$ explored; the possibility of adapting the negative ${ }_{-}^{-}$ staining methods of electron microscopy to

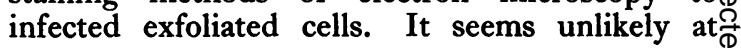




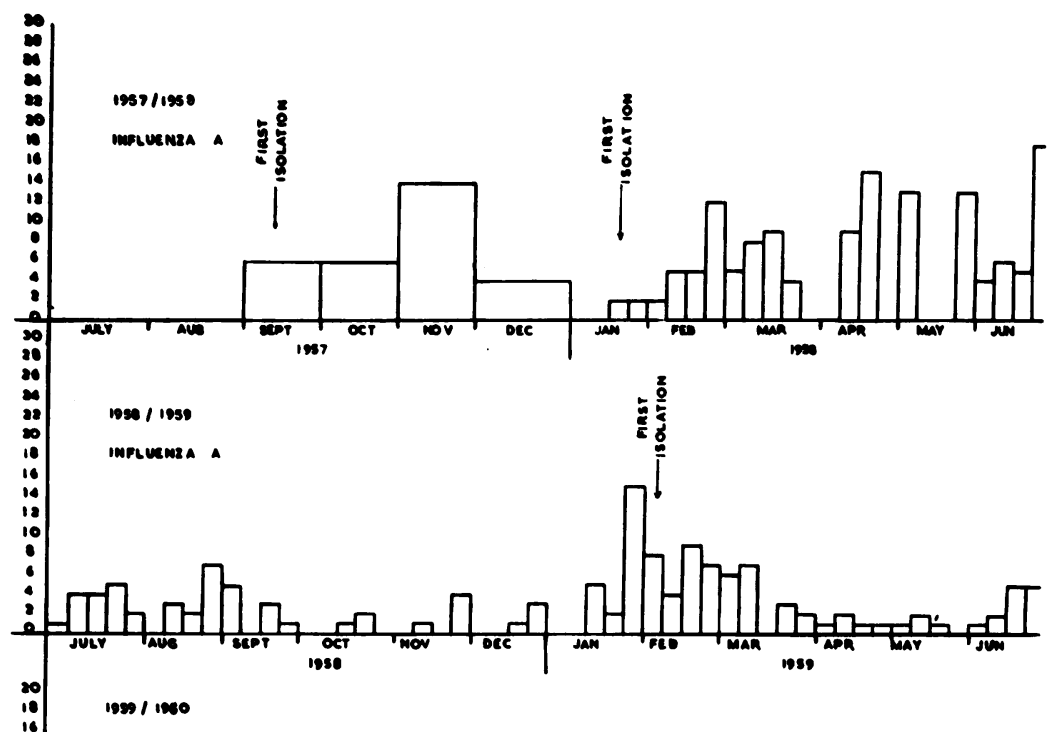

imfluemza a
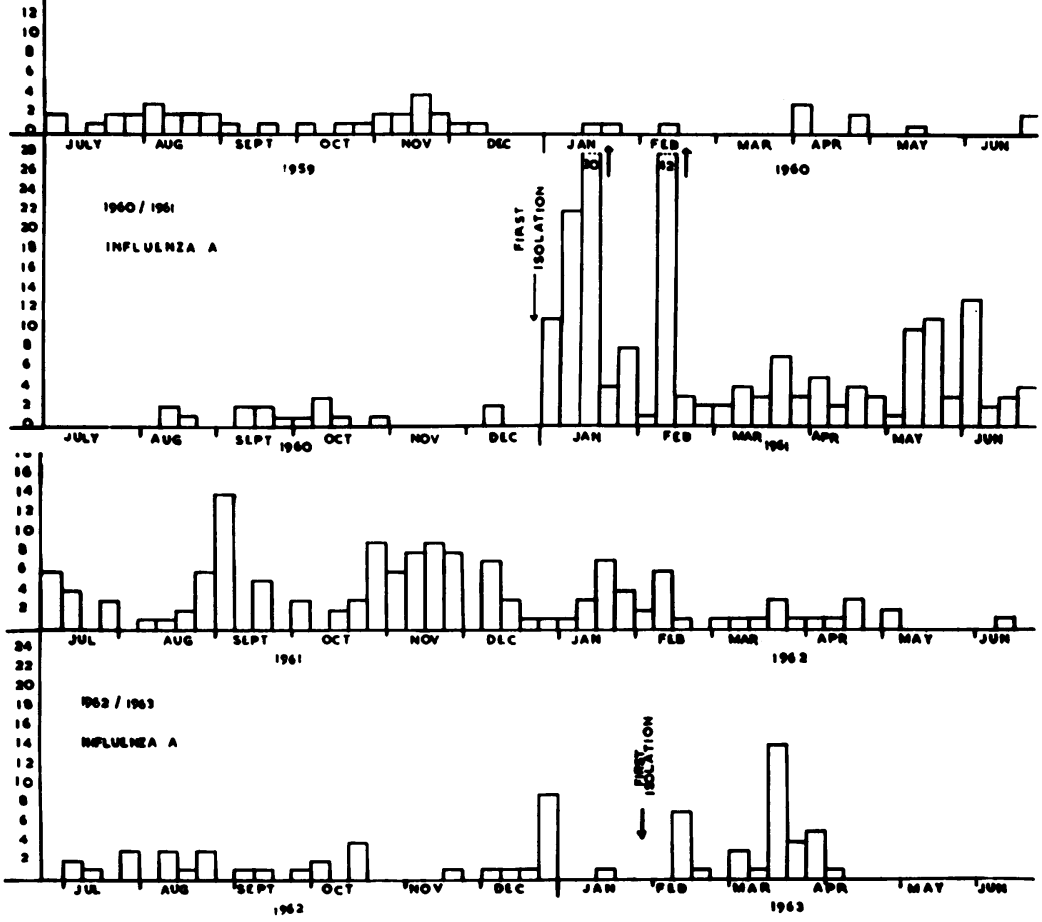

present that it would be possible thus to discriminate between different kinds of myxovirus; but technical advances in this field are coming along rapidly and we shall have to wait and see.
I should like to thank the Head of the Physics Department, Birmingham College of Advanced Technology, for kindly allowing me to use their electron microscope. 
Clarke, S. K. R., Heath, R. B., Sutton, B. M., Sutron, R. N. P., and Stuart-Harris, C. H. (1958): Serological Studies with Asian Strain of Influenza A, Lancet, i, 8 I4.

Grist, N. R., KerR, J., and IsaAcs, B. (196r): Rapid Serological Diagnosis of an Outbreak of Influenza, Brit. med. $\mathcal{F} ., \subseteq$ ii, 431 .

Hers, J. F. Ph. (1960): Studies on Influenza-Virus Pneumonia in Human Beings and in Mice Using Fluoresceinlabelled Antibodies. In, Boerhaave Cursus, Proceedings, Fluorescent Antibody Technique. Leiden.

- - and Mulder, J. (1961): Broad Aspects of the Pathology and Pathogenesis of Human Influenza, Amer. Rev. resp. Dis., 83 (Part 2), 84.

IsaAcs, A., HaRT, R. J. C., and Law, V. (1961): Influenza Viruses, 1957-60, Bull. Wld Hlth Org., 26, 253.

Jensen, K. E. (1961): Diagnosis of Influenza by Serologic Methods, Amer. Rev. resp. Dis., 83 (Part 2 ), i 20. , Dunn, F. L., and RoBinson, R. Q. (1958): Influenza, 1957: A Variant and the Pandemic, in 'Prog. Med. Virol',
Vol. I. Ed.: E. Berger and J. L. Melnick. Basel and New York: S. Karger.

Liv, C. (1956): Rapid Diagnosis of Human Influenza Infection from Nasal Smears by Means of Fuorescein-labelled $\vec{\circ}$ Antibody, Proc. Soc. exp. Biol., 92, 883.

(1961): Diagnosis of Influenza Infection by Means of Fluorescent Antibody Staining, Amer. Rev. resp. Dis., 83 (Part 2), i3o.

MaAssab, H. F. (1961): Contribution to Discussion, International Conference on Asian Influenza, Ibid., 83 (Part 2), 138. 응

\section{Discussion}

Dr. HeARN asked whether one could predict when an epidemic was due to develop by investigation of virus isolations.

A Participant answered that the arrival of the Asian epidemic had been predicted months in advance, and a vaccine was ready before the epidemic struck. Influenza epidemic arising from a recent variation already in that community was more difficult, although the Ministry of Health was now very nearly able to predict an epidemic from the weekly reports coming from various sources.

Dr. RoDEN said it was difficult to attempt to predict what was going to happen. 'This year's experience was that for several weeks the epidemic spread of influenza was restricted to London and south-east England. He would enlarge on problems of prediction in his paper.

Dr. A. J. Beale asked ( $\mathrm{I}$ ) whether one could assess the level of immunity in the population by examining sera; and (2) what was the pathogenesis of influenzal encephalitis?

DR. FLEWETT replied that the only convenient way of investigating the antibody content of large numbers $\infty$ of sera was by the hæmagglutination-inhibition method; many sera contained non-specific inhibitors, especially 은 active against Asian virus, and there was so far no really satisfactory means of getting rid of these completely. An assessment of the immune state of a population based on this method might be misleading; and the $\frac{0}{0}$ infectivity-neutralization method was so expensive to $\underline{\mathbb{Q}}$ do as not to be really practical on a large scale. Ang how, it would only tell you what viruses people hag suffered from, not how they would respond to the next variant. Professor StUART-Harris agreed. DP FLEWETT said no one knew the pathogenesis of post influenzal encephalitis; there was no good evidence that the virus multiplied in human brain. One might theorize that the virus caused cell damage and release of cell constituents leading to formation of anti-brain $\stackrel{\circ}{\varnothing}$ antibodies and hence 'auto-immune' encephalitis, but there was no good evidence that this actually happened. $\overrightarrow{\vec{O}}$ Dr. S. C. Melnick had been unable to demonstrate a 3 significant incidence of circulating antibodies to brain extracts in cases of encephalitis following measles, chickenpox, etc.

\section{Discussion following the papers by Professor Stuart-Harris, Dr. Hearn and Dr. Hill}

Dr. Morrison Smith remarked that he had found that influenza was not devastating in children with severe chronic asthma, and could not recall having lost an asthmatic child in Birmingham from influenza.

Professor Melville ArnotT said that the asthma appeared to go into cold storage during influenza.

Drs. Pinsent, Hearn and Brian Taylor all confirmed this from their experience.

Dr. FleweTt asked Professor Stuart-Harris if he would comment further on Kilbourne's views about the unchanging virulence of the influenza virus; if one accepted this, how could the death rates in Liverpool and Belfast of over 800 in a week in $195 \mathrm{I}$ be explained?
Professor StUART-Harris replied that the deaths were mainly in people over the age of 65 , and referred to a paper by Francis suggesting that the death rate from pneumonia was fairly constantly proportional to $N$ the attack rate in the population; but agreed that the evidence was inadequate to come to a firm conclusion.

A QUESTIONER suggested that in the severe pandemic of 1918-19 many deaths might have been caused by malnutrition plus influenza, and remarked that reports 0 of post-influenzal depression were exaggerated; much $\stackrel{\complement}{\Phi}$ of it was really an exacerbation or precipitation of preexisting mental illness. 